\title{
Conversion of Isoprenoid Oil by Catalytic Cracking and Hydrocracking over Nanoporous Hybrid Catalysts
}

\author{
Toshiyuki Kimura, ${ }^{1}$ Chen Liu, ${ }^{2}$ Xiaohong Li, ${ }^{1}$ Takaaki Maekawa, ${ }^{3}$ and Sachio Asaoka ${ }^{1}$ \\ ${ }^{1}$ Graduate School of Environmental Engineering, The University of Kitakyushu, 1-1 Hibikino, Wakamatsu, Kitakyushu, \\ Fukuoka 808-0135, Japan \\ ${ }^{2}$ Environmental Geochemistry, China University of Geosciences, 29 Xueyuan Lu, Beijing 100083, China \\ ${ }^{3}$ Research Institute of Tsukuba Bio-Tech Corporation, 2-10-1 Matsushiro, Ibaraki Tsukuba 305-0035, Japan \\ Correspondence should be addressed to Sachio Asaoka, asaoka@kitakyu-u.ac.jp
}

Received 20 February 2012; Revised 15 April 2012; Accepted 29 April 2012

Academic Editor: Claudio M. Soares

Copyright ( $\odot 2012$ Toshiyuki Kimura et al. This is an open access article distributed under the Creative Commons Attribution License, which permits unrestricted use, distribution, and reproduction in any medium, provided the original work is properly cited.

In order to produce petroleum alternatives from biomass, a significant amount of research has been focused on oils from microalgae due to their origin, which would not affect food availability. Nanoporous hybrid catalysts composed of $\mathbf{n s} \mathrm{Al}_{2} \mathrm{O}_{3}$ and zeolites have been proven to be very useful compared to traditional catalysts in hydrotreating (HT), hydrocracking (HC), and catalytic cracking (CC) of large molecules. To evaluate the reaction scheme and products from model isoprenoid compounds of microalgae oil, nanoporous hybrid catalyst technologies (CC: $\mathbf{n s ~} \mathrm{Al}_{2} \mathrm{O}_{3} / \mathrm{H}-\mathrm{USY}$ and $\mathbf{n s} \mathrm{Al}_{2} \mathrm{O}_{3} / \mathrm{H}-\mathrm{GaAlMFI}$; HC: [Ni-Mo/ $\gamma$ $\left.\mathrm{Al}_{2} \mathrm{O}_{3}\right] / \mathbf{n s ~} \mathrm{Al}_{2} \mathrm{O}_{3} / \mathrm{H}$-beta) were studied. The major product from $\mathrm{CC}$ on $\mathbf{n s ~} \mathrm{Al}_{2} \mathrm{O}_{3} / \mathrm{H}$-USY was highly aromatic gasoline, while the product from HC was half-isoparaffinic/olefinic kerosene. Although more than $50 \mathrm{wt} \%$ of the products from HT/CC on the USY catalyst was liquefied petroleum gas due to overcracking, the product from HT/CC on the MFI catalyst was high-octane-number gasoline. Delightfully, the product from HT/HC was kerosene and its average number was 11, with more than $80 \mathrm{wt} \%$ being isoparaffinic. As a result, it was demonstrated that hydrotreating may convert isoprenoid oil from microalgae over nanoporous hybrid catalysts into a variety of products.

\section{Introduction}

For more than three centuries, fossil fuels have been used in various aspects of our lives; however, these fuels are not renewable and will eventually be depleted. In fact, over $80 \%$ of the energy we use comes from petroleum, coal, and natural gas. About $98 \%$ of carbon emissions are due to fossil fuel combustion, resulting in large amounts of carbon dioxide being discharged into the atmosphere [1]. It is possible to reduce carbon dioxide emissions by reducing the amount of fossil fuels used. Biomass is one of the most potentially energetic organic resources to replace fossil fuels, because it is renewable and neutral with regard to carbon dioxide emissions. Recently, many researchers have studied synthetic hydrocarbon fuels from various biomass sources, for example, wheat, soy beans, sugar cane, corn, rapeseed and palm oils [2-9], or woody cellulose [10-12]. However, biomass has become a problem since it may affect food availability. Therefore, attention has turned to microalgae oil as a new renewable energy source. Production of biofuels from microalgae consists of culturing microalgae and producing hydrocarbon fuels from the resulting oil. This paper will focus on the latter stage of fuel production from microalgae. Recently, microalgae oil has been used to produce hydrocarbon fuels and gas or other related products [13-19].

Microalgae oil can be divided into two types: a triglyceride series and an isoprenoid series. The triglyceride series is produced by Euglena and others, and the isoprenoid series is produced by Botryococcus braunii and others. Conversion of triglyceride fatty oil to fuels has generally been performed by transesterification using an alkali catalyst to produce biodiesel fuels (BDF) [20-22]. The main component in BDF is fatty acid methyl ester (FAME). FAME can be used directly in diesel engines, but it cannot replace gasoline and jet 
fuels. In practice, $\mathrm{BDF}$ is used by mixing about $3 \% \mathrm{BDF}$ with gasoline and jet fuels. Because BDF tends to contain some impurities, for example, oxygen and nitrogen, it causes damage to engines. Additionally, FAME is costly because it requires a large amount of methanol, and this must be separated from the final product. Thus, some problems still remain in using $\mathrm{BDF}$ as a renewable new energy source to replace gasoline and jet fuels.

In contrast, the microalgae oil produced by Botryococcus braunii is botryococcene, an isoprenoid hydrocarbon of 27-34 carbon atoms with a relatively high melting point, which is easy to handle and does not corrode equipment. The coauthor previously studied the catalytic cracking of isoprenoid oil extracted from Botryococcus braunii using the traditional catalytic cracking catalyst [23]. The main products were gasoline, light cycle oil, and heavy cycle oil. It was confirmed that the reactivity and products correlated with the catalytic cracking of squalene. Recently, studies on the fuel synthesis process and catalyst from botryococcene and/or squalene have been reported [24-27].

Our current research has been intentionally focused on composites containing unimodal nanoporous nanosized (defined as $5-50 \mathrm{~nm}$, and hereafter referred to as $\mathbf{n s ) ~ o x i d e s ~}$ with pore sizes ranging from about $5 \mathrm{~nm}$ to several tens of nanometers [28]. This research yielded some advances in catalysis, including hydrodesulfurization $[29,30]$, hydrocracking [31-35], reforming [36-38], and catalytic cracking $[39,40]$. Various ns alumina matrices with different properties were studied for catalytic cracking catalysts. The activity was found to be dependent on the pore size of the matrix because precracking proceeds independently from the zeolite component. An inverse relationship was also demonstrated between the activity and the rate of degradation by coking, both of which were analyzed as a function of the pore diameter of the matrix. For hydrocracking and isomerization catalysts, a tricomponent catalyst consisting of beta zeolite, ns oxide, and metal $/ \gamma-\mathrm{Al}_{2} \mathrm{O}_{3}$ was studied. This catalyst has relatively high selectivity for hydroreforming large $n$ paraffins to lighter isoparaffins. The enhanced catalytic performance is due to the combined effects of zeolite, ns oxide, and metal $/ \gamma-\mathrm{Al}_{2} \mathrm{O}_{3}$. Catalysts containing dealuminated beta zeolite with $\mathbf{n s ~} \mathrm{Al}_{2} \mathrm{O}_{3}$ have high conversion and isoselectivity; their catalytic performances are suitable for producing isoparaffins for gasoline. Therefore, the conversions of squalene and squalane, selected as models of microalgae oil and its hydrotreated version, respectively, were studied by catalytic cracking and hydrocracking on our own catalysts.

\section{Experimental}

2.1. Catalyst Preparation. Three types of catalysts for catalytic cracking were prepared using the following reagents [37-40]. Two kinds of zeolites, the commercial USY zeolite $\left(\mathrm{SiO} / \mathrm{Al}_{2} \mathrm{O}_{3}\right.$ molar ratio $\left.=12\right)$ (JGC Catalysts and Chemicals, LTD.) and lab-made $\mathrm{H}$-GaAlMFI zeolite $\left(\mathrm{SiO}_{2} / \mathrm{Al}_{2} \mathrm{O}_{3}\right.$ molar ratio $=30$ ) were chosen as the zeolite catalyst component. The H-GaAlMFI zeolite was synthesized using sodium silicate, aluminum sulfate $14-18$ hydrate $\left(\mathrm{Al}_{2}\left(\mathrm{SO}_{4}\right)_{3} \cdot 14\right.$ $\left.18 \mathrm{H}_{2} \mathrm{O}\right)$, gallium nitrate $n$ hydrate $\left(\mathrm{Ga}\left(\mathrm{NO}_{3}\right)_{2} \cdot n \mathrm{H}_{2} \mathrm{O}\right)$, tetrapropylammonium bromide (TPABr), sodium chloride, sulfuric acid, and deionized water. These reagents were mixed sequentially. The mixture was aged overnight at room temperature, then the zeolite was hydrothermally synthesized at $150^{\circ} \mathrm{C}$ for $24 \mathrm{~h}$. The synthesized zeolite was washed with $\mathrm{H}_{2} \mathrm{O}$ until the $\mathrm{pH}$ reached 7 , then dried overnight at room temperature. Further drying was conducted at $120^{\circ} \mathrm{C}$ for $3 \mathrm{~h}$, followed by calcination in air at $550^{\circ} \mathrm{C}$ for $3 \mathrm{~h}$. A moderate developed kind of dry unimodal boehmite sol powder was prepared by the hydrothermal aging method. The powder can be converted to a type of $\mathbf{n s} \mathrm{Al}_{2} \mathrm{O}_{3}$ matrix material with a unimodal pore diameter of $14 \mathrm{~nm}$ by calcination, as reported previously $[39,40]$. Two of these solid powders were mixed with water to form a thick paste and this paste was mechanically kneaded. After kneading, the catalysts were extruded into pellets, then dried overnight at room temperature and heated at $120^{\circ} \mathrm{C}$ for $3 \mathrm{~h}$. Finally, they were calcinated at $550^{\circ} \mathrm{C}$ for $3 \mathrm{~h}$. The $\mathbf{n s} \mathrm{Al}_{2} \mathrm{O}_{3} / \mathrm{GaAlMFI}$ catalysts pellets were converted into $\mathrm{H}$-type zeolites by a conventional ion exchange method with an aqueous solution of $2.2 \mathrm{~mol} / \mathrm{L}$ $\mathrm{NH}_{4} \mathrm{NO}_{3}$. The catalysts were made from $\mathbf{n s} \mathrm{Al}_{2} \mathrm{O}_{3}$ and zeolite (dry weight ratio: $70: 30$ ).

$\left[\mathrm{NiMo} / \gamma-\mathrm{Al}_{2} \mathrm{O}_{3}\right] / \mathbf{n s} \quad \mathrm{Al}_{2} \mathrm{O}_{3} / \mathrm{H}$-beta zeolite catalyst was prepared for hydrocracking with isomerization [31-35]. The $\mathrm{NiMo} / \gamma-\mathrm{Al}_{2} \mathrm{O}_{3}$ catalyst was prepared by coimpregnation using the incipient wetness method. Two catalysts were loaded with $0.39 \mathrm{~g} / \mathrm{g}-\left(\gamma-\mathrm{Al}_{2} \mathrm{O}_{3}\right)$ and $0.36 \mathrm{~g} / \mathrm{g}-\left(\gamma-\mathrm{Al}_{2} \mathrm{O}_{3}\right)$ of $\mathrm{Ni}\left(\mathrm{NO}_{3}\right)_{2} \cdot 6 \mathrm{H}_{2} \mathrm{O}$ and $\left(\mathrm{NH}_{4}\right)_{6} \mathrm{Mo}_{7} \mathrm{O}_{24} \cdot 4 \mathrm{H}_{2} \mathrm{O}$ in the following manner. A laboratory-produced $\mathrm{Al}_{2} \mathrm{O}_{3}$ extrudate with $11 \mathrm{~nm}$ unimodal pores and a high-surface area of $225 \mathrm{~m}^{2} / \mathrm{g}$ was used as the metal carrier. $100 \mathrm{~g}$ of the alumina extrudate was impregnated with the Ni-Mo metal solution. A solution of $39 \mathrm{~g}$ of nickel nitrate hexahydrate $\left[\mathrm{Ni}\left(\mathrm{NO}_{3}\right)_{2} \cdot 6 \mathrm{H}_{2} \mathrm{O}\right]$ was prepared in $40 \mathrm{~mL}$ of water. Similarly, $36 \mathrm{~g}$ of hexaammonium heptamolybdate tetrahydrate $\left[\left(\mathrm{NH}_{4}\right)_{6} \mathrm{Mo}_{7} \mathrm{O}_{24} \cdot 4 \mathrm{H}_{2} \mathrm{O}\right]$ was dissolved in $40 \mathrm{~mL}$ of water and heated at $40 \sim 50^{\circ} \mathrm{C}$ to dissolve the solid. The two solutions were mixed and quickly added to the extrudates. They were then mixed well to ensure that the alumina was homogeneously impregnated by the solution. The mixing and impregnation were performed quickly to avoid complex formation between the two solutions. The impregnated extrudate was aged overnight in a sealed container at room temperature. It was then dried at $120^{\circ} \mathrm{C}$ for $5 \mathrm{~h}$ and calcined at $550^{\circ} \mathrm{C}$ for $2 \mathrm{~h}$. A metalimpregnated alumina $\left(\mathrm{NiMo} / \gamma-\mathrm{Al}_{2} \mathrm{O}_{3}\right)$ powder (particle size: $15 \mu \mathrm{m}$ ) was obtained by grinding the catalyst. Cataloid AP-1 (JGC Catalyst and Chemical, LTD.) was used as the $\mathbf{n s} \mathrm{Al}_{2} \mathrm{O}_{3}$ precursor for the hydrocracking catalyst. The precursor consists of $71.0 \mathrm{wt} \%$ alumina, $11.0 \mathrm{wt} \%$ acetic acid, and $18.0 \mathrm{wt} \%$ water and has an average particle size of $5.4 \mathrm{~nm}$. $\mathrm{H}$-beta zeolite $\left(\mathrm{SiO}_{2} / \mathrm{Al}_{2} \mathrm{O}_{3}\right.$ molar ratio $\left.=25\right)$ is a commercial zeolite (Sud-Chemie Catalysts Japan, Inc.). [ $\mathrm{NiMo} / \gamma$ $\left.\mathrm{Al}_{2} \mathrm{O}_{3}\right] / \mathbf{n s} \mathrm{Al}_{2} \mathrm{O}_{3} / \mathrm{H}$-beta zeolite catalyst was synthesized by wet mixing followed by calcination. Three of these solid powders were mixed with water to form a thick paste and this paste was mechanically kneaded. After kneading, the catalysts were extruded into pellets. They were then dried overnight at room temperature and heated at $120^{\circ} \mathrm{C}$ for $3 \mathrm{~h}$. Finally, they were calcined in air at $550^{\circ} \mathrm{C}$ for $3 \mathrm{~h}$. 
The tri-component catalysts were made from $\mathrm{NiMo} / \gamma$ $\mathrm{Al}_{2} \mathrm{O}_{3}$, ns $\mathrm{Al}_{2} \mathrm{O}_{3}$, and $\mathrm{H}$-beta zeolite (dry weight ratio of $2: 1: 2$ ).

2.2. Reaction Test and Catalyst Evaluation. The performances of the catalysts were evaluated using a feedstock of squalene (iso- $\mathrm{C}_{30} \mathrm{H}_{50}$ ) and its hydrotreated form, squalane (iso$\mathrm{C}_{30} \mathrm{H}_{62}$ ), which have normal boiling points of $285^{\circ} \mathrm{C}$ and $350^{\circ} \mathrm{C}$, respectively. These were selected as model compounds of microalgae oil.

A continuous-flow reactor with a down flow-type fixed bed catalyst (volume: $0.5 \mathrm{~mL}$ ) was used for the reaction tests. Reaction conditions were as follows: temperature, $250 \sim 550^{\circ} \mathrm{C}$; liquid hourly space velocity (LHSV), 7.2 $40 \mathrm{~h}^{-1}$ (contact time (1/LHSV), $0.025 \sim 0.50 \mathrm{~h}$ ); pressure, $0.12 \mathrm{MPa}$ under nitrogen or hydrogen atmosphere; molar ratio of iso- $\mathrm{C}_{30} \mathrm{H}_{50}$ or iso- $\mathrm{C}_{30} \mathrm{H}_{62}: \mathrm{N}_{2}$ or $\mathrm{H}_{2}, 1: 15$.

The acid amount was measured by the $\mathrm{NH}_{3}-\mathrm{TPD}$ method [33]. Mesoporosity was measured using nitrogen adsorption-desorption isotherms [40]. Elemental composition of the catalyst surface layer was determined by Xray photoelectron spectroscopy (XPS) using a KRATOS equipped with a mono $\mathrm{Al}$ source operating at $450 \mathrm{~W}$. The spectra were acquired at room temperature with narrow scans using rather high $40 \mathrm{eV}$ pass energy for the samples. The spectrometer energy scale was calibrated with $\mathrm{Ag} 3 \mathrm{~d} 5 / 2$. The binding energies and atomic concentrations of the catalysts were calculated from the XPS results using the total integrated peak areas of the $\mathrm{Al} 2 \mathrm{p}, \mathrm{Si} 2 \mathrm{p}, \mathrm{Ga} 2 \mathrm{p}, \mathrm{O}$ 1s, and C 1 s regions.

\section{Results and Discussion}

3.1. Catalytic Cracking of Nonhydrotreated Oil. The ns $\mathrm{Al}_{2} \mathrm{O}_{3} /$ USY zeolite catalyst was developed as a fluid catalytic cracking catalyst in our previous research $[39,40]$. It was confirmed that a catalyst with a middle pore size of around $14 \mathrm{~nm}$ made from two different pore sizes of $\mathbf{n s} \mathrm{Al}_{2} \mathrm{O}_{3}$ of $7 \mathrm{~nm}$ and $35 \mathrm{~nm}$ exhibited higher cracking activity and a lower rate of degradation by coking. The properties of the catalyst are shown in Table 1. Catalytic cracking of nonhydrotreated oil, squalene, was investigated over the ns $\mathrm{Al}_{2} \mathrm{O}_{3}$ /USY zeolite catalyst at temperatures in the range 400 to $500^{\circ} \mathrm{C}$. The results are shown in Figures 1 and 2 .

As shown in Figure 1, conversions were almost $100 \%$ and olefins were produced at about $50 \%$ selectivity at all temperatures. Aromatics were produced at about $40 \%$ selectivity at $500^{\circ} \mathrm{C}$. As shown in Figure 2, the product distribution of carbon number peaked at nine with the main products being aromatics. It is considered that $\mathrm{C}_{8}$ and $\mathrm{C}_{9}$ olefins caused cyclization and aromatization reactions, resulting in hydrogenation of the highly unsaturated olefins by hydrogen transfer. The equilibrium between the hydrogenation and dehydrogenation reactions was balanced such that hydrogen gas was not used substantially in the reaction system.

3.2. Hydrocracking of Nonhydrotreated Oil. In our previous research, it was confirmed that the tri-component catalyst consisting of $\mathrm{NiMo} / \gamma-\mathrm{Al}_{2} \mathrm{O}_{3}$, ns $\mathrm{Al}_{2} \mathrm{O}_{3}$, and H-beta zeolite

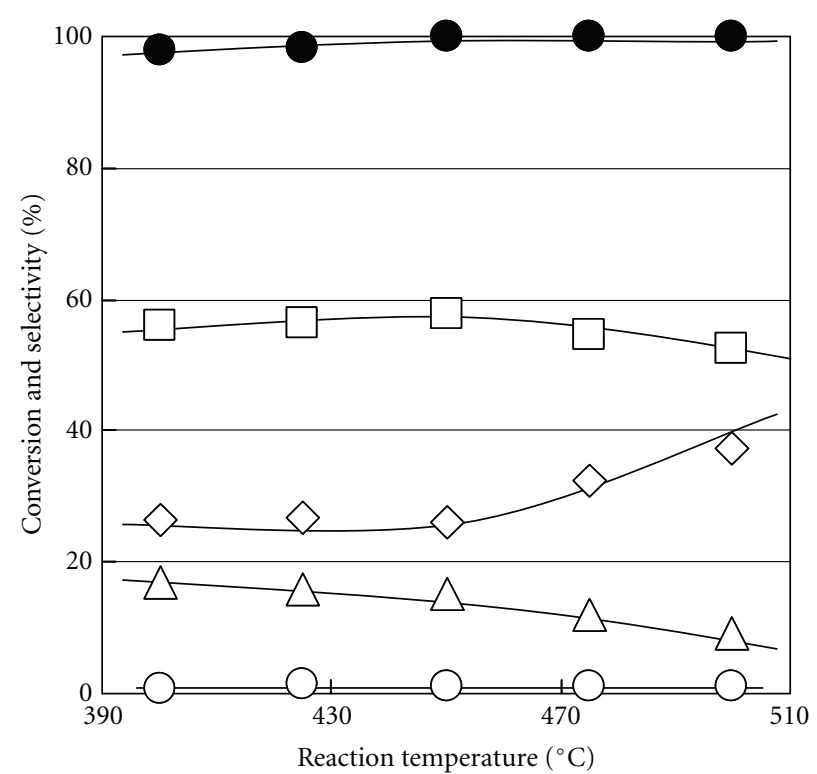

FIGURE 1: Conversion and product selectivity of catalytic cracking of nonhydrotreated oil over ns $\mathrm{Al}_{2} \mathrm{O}_{3}$ /USY Ccatalyst depending on reaction temperature. 0 : Conversion; selectivity: $\bigcirc$ : normal paraffins; $\triangle$ : isoparaffins; $\square$ : olefins; $\diamond$ : aromatics.

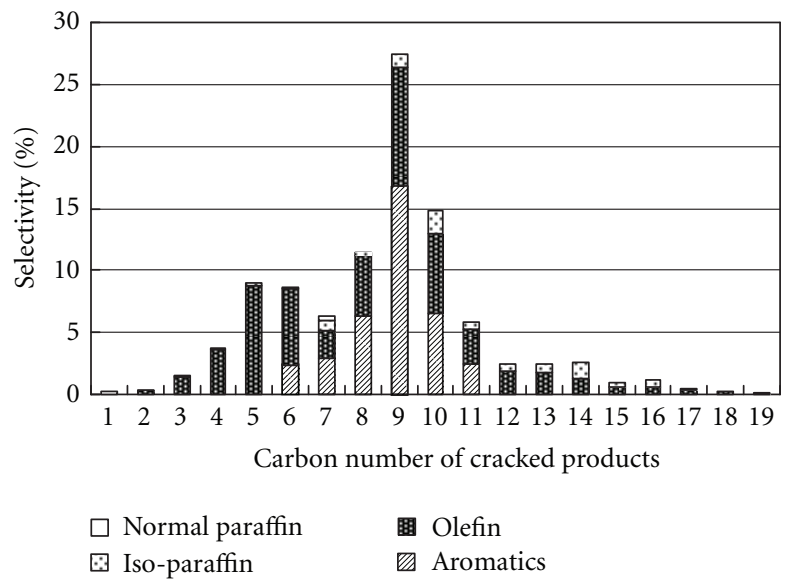

FIgURe 2: Product distribution over $\mathbf{n s ~} \mathrm{Al}_{2} \mathrm{O}_{3} / \mathrm{USY}$ zeolite catalyst at $500^{\circ} \mathrm{C}$.

TABLE 1: Basic physical properties of $\mathbf{n s ~} \mathrm{Al}_{2} \mathrm{O}_{3} /$ USY zeolite catalysts.

\begin{tabular}{lccc}
\hline Catalysts & $\begin{array}{c}\text { Surface area } \\
\left(\mathrm{m}^{2} / \mathrm{g}\right)\end{array}$ & $\begin{array}{c}\text { Pore volume } \\
(\mathrm{mL} / \mathrm{g})\end{array}$ & $\begin{array}{c}\text { Average pore } \\
\text { diameter }(\mathrm{nm})\end{array}$ \\
\hline $\mathbf{n s ~} \mathrm{Al}_{2} \mathrm{O}_{3}$ & 200 & 0.44 & 14.1 \\
$\mathrm{USY}$ & 650 & 0.17 & 3.0 \\
$\mathbf{n s ~} \mathrm{Al}_{2} \mathrm{O}_{3} / \mathrm{USY}$ & 480 & 0.42 & 9.2 \\
$\mathbf{n s ~} \mathrm{Al}_{2} \mathrm{O}_{3} / \mathrm{USY}^{*}$ & 515 & 0.25 & 6.3 \\
\hline
\end{tabular}

* Theoretical addition by composition.

had relatively high selectivity for hydroreforming large nparaffins to lighter isoparaffins [35]. As shown in Figure 3, $\mathrm{H}$-beta zeolite bound with $\mathbf{n s ~} \mathrm{Al}_{2} \mathrm{O}_{3}$ had more acid content 


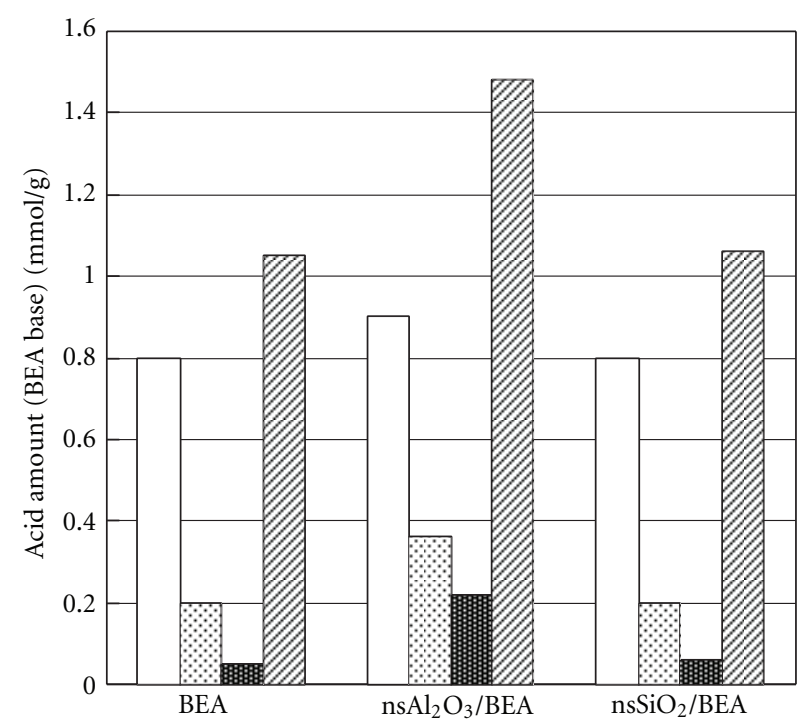

FIGURE 3: Generated acid sites at the boundary between $\mathbf{n s ~} \mathrm{Al}_{2} \mathrm{O}_{3}$ and $\mathrm{H}$-beta Zeolite. White region: weak acid sites* 1 ; dotted region: mild moderate acid sites*2; black region: mild strong acid sites; shaded region: total acid sites $3^{*} 1: 200^{\circ} \mathrm{C}$ peak; ${ }^{*} 2: 310^{\circ} \mathrm{C}$ peak; ${ }^{*} 3$ : $410^{\circ} \mathrm{C}$ peak.

than only $\mathrm{H}$-beta zeolite, and the increased acids consist of mild-moderate acid and mild-strong acid. On the other hand, H-beta zeolite bound with ns $\mathrm{SiO}_{2}$ had almost the same acid content of only $\mathrm{H}$-beta zeolite. It is considered that the generated acid sites at the boundary between $\mathbf{n s} \mathrm{Al}_{2} \mathrm{O}_{3}$ and nanoporous zeolite were derived from pseudoboehmite and H-beta zeolite. Hydrocracking of nonhydrotreated squalene was investigated over $\left[\mathrm{NiMo} / \gamma-\mathrm{Al}_{2} \mathrm{O}_{3}\right] / \mathbf{n s ~} \mathrm{Al}_{2} \mathrm{O}_{3} / \mathrm{H}$-beta zeolite catalyst at temperatures in the range 250 to $350^{\circ} \mathrm{C}$. The results are shown in Figures 4 and 5.

As shown in Figure 4, the selectively for isoparaffins was about 35\%, while aromatics selectivity was about $40 \%$ at $350^{\circ} \mathrm{C}$. As shown in Figure 5, the product distribution of carbon number in hydrocracking also had a peak at nine, similar to catalytic cracking. The main aromatics were xylenes and trimethylbenzenes. Thus, large amounts of aromatics were produced despite the hydrocracking reaction. It was considered that the cracking reaction was suppressed because the reaction temperature of hydrocracking is lower than that of catalytic cracking. Therefore, aromatization progressed much further, resulting in highly unsaturated products of 8 9 carbon atoms. The reaction scheme of catalytic cracking and hydrocracking of nonhydrotreated oil based on Figures 2 and 5 is summarized in Figure 6.

As shown in Figure 6, in the case of catalytic cracking of nonhydrotreated oil, aromatics are produced by aromatization and transhydrogenation of cracked $\mathrm{C}_{8} \sim \mathrm{C}_{9}$ olefins with hydrogen transfer as a result of the high temperature and lack of hydrogen in the reaction system. In the case of hydrocracking, aromatics are similarly produced by aromatization of cracked $\mathrm{C}_{8} \sim \mathrm{C}_{9}$ olefins. In this reaction system, olefins were converted to paraffins, and hydrogen transfer proceeded more often than in catalytic cracking.

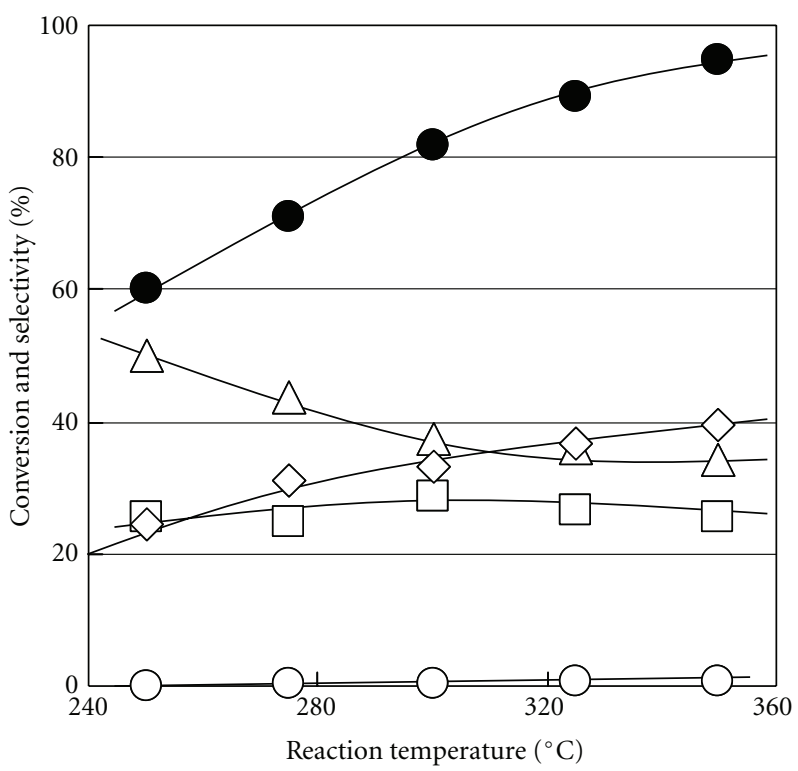

FIgure 4: Conversion and pProduct selectivity of hydrocracking of nonhydrotreated oil over $\left[\mathrm{NiMo} / \gamma-\mathrm{Al}_{2} \mathrm{O}_{3}\right] / \mathbf{n s} \quad \mathrm{Al}_{2} \mathrm{O}_{3} / \mathrm{H}$-beta zeolite catalyst depending on reaction temperature. Conversion; selectivity: $\bigcirc$ : normal paraffins; $\triangle$ : isoparaffins; $\square$ : olefins; $\diamond$ : aromatics.

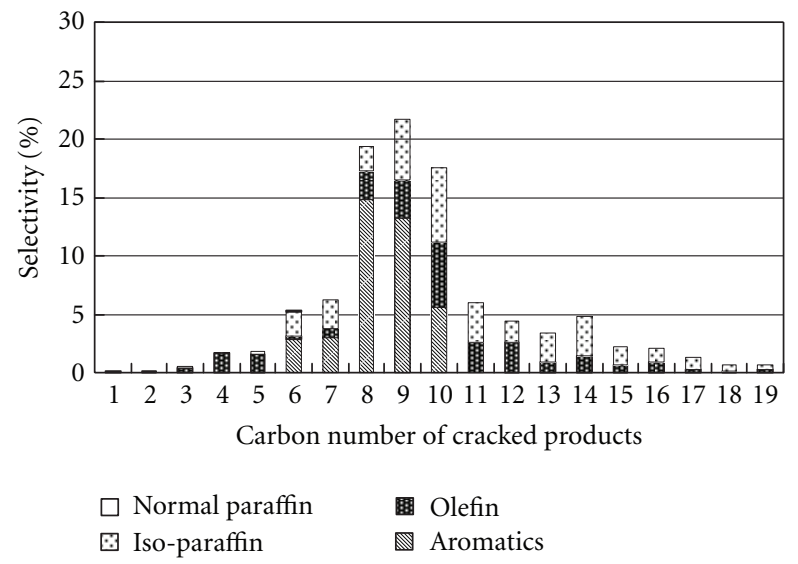

Figure 5: Product distribution from hydrocracking of nonhydrotreated oil over $\left[\mathrm{NiMo} / \gamma-\mathrm{Al}_{2} \mathrm{O}_{3}\right] / \mathbf{n s ~} \mathrm{Al}_{2} \mathrm{O}_{3} / \mathrm{H}$-beta zeolite catalyst at $350^{\circ} \mathrm{C}$.

It was revealed that a large amount of olefins and aromatics was inevitably produced from nonhydrotreated oil of highly unsaturated olefins.

\subsection{Catalytic Cracking of Hydrotreated Oil}

3.3.1. ns $\mathrm{Al}_{2} \mathrm{O}_{3} / \mathrm{H}$-USY Zeolite Catalyst. Catalytic cracking of hydrotreated oil, squalane, was investigated over ns $\mathrm{Al}_{2} \mathrm{O}_{3} / \mathrm{USY}$ zeolite catalyst at temperatures in the range 300 to $500^{\circ} \mathrm{C}$. The results are shown in Figures 7 and 8 .

As shown in Figure 7, this catalyst showed very high activity (more than $90 \%$ conversion at $350^{\circ} \mathrm{C}$ ) and aromatics 


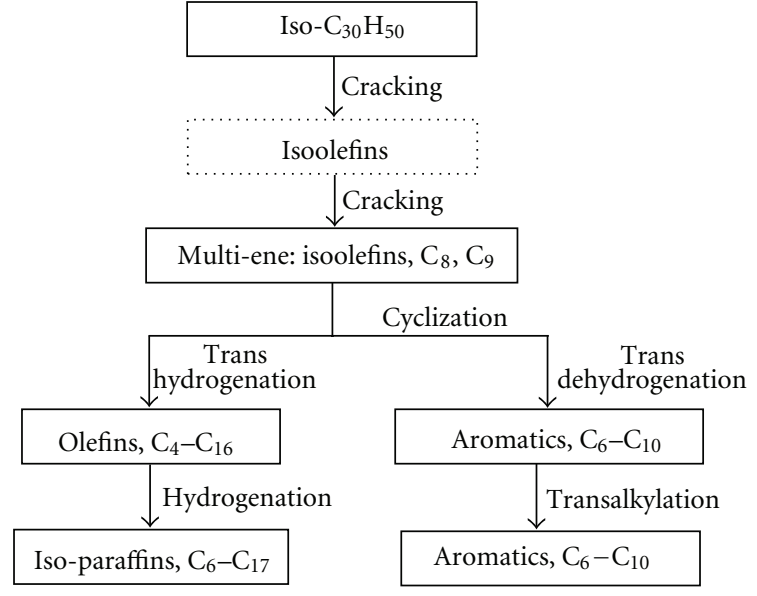

Figure 6: Reaction Scheme of Catalytic Cracking and Hydrocracking of Nonhydrotreated Oil Based on Figures 2 and 5.

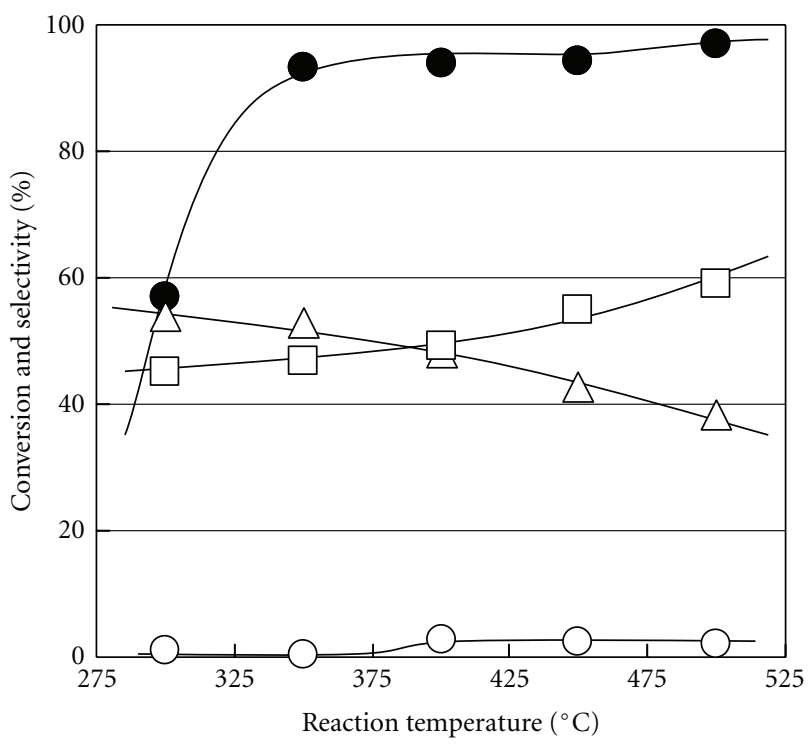

FIGURE 7: Conversion and product selectivity of catalytic cracking of hydrotreated oil over $\mathbf{n s} \mathrm{Al}_{2} \mathrm{O}_{3} /$ USY catalyst depending on reaction temperature. 0 : Conversion; selectivity: $\bigcirc$ : normal paraffins; $\triangle$ : isoparaffins; $\square$ : olefins.

were not produced at any of the reaction temperatures. It was revealed that isoparaffins used as feedstock were easier to decompose at low temperatures. In addition, olefins were produced by the cracking reaction without aromatization because there were enough paraffins in the reaction system to keep the equilibrium far from highly unsaturated olefins.

As shown in Figure 8, the product distribution of carbon number in catalytic cracking of hydrotreated oil at $350^{\circ} \mathrm{C}$ still had a peak at nine. On the other hand, overcracking occurred at the higher temperature. The product distribution of carbon number at $550^{\circ} \mathrm{C}$ had a peak at three (data not shown). It was demonstrated that the optimum reaction temperature to obtain useful products in catalytic cracking of hydrotreated oil on $\mathbf{n s ~} \mathrm{Al}_{2} \mathrm{O}_{3} / \mathrm{USY}$ catalyst was $350^{\circ} \mathrm{C}$.

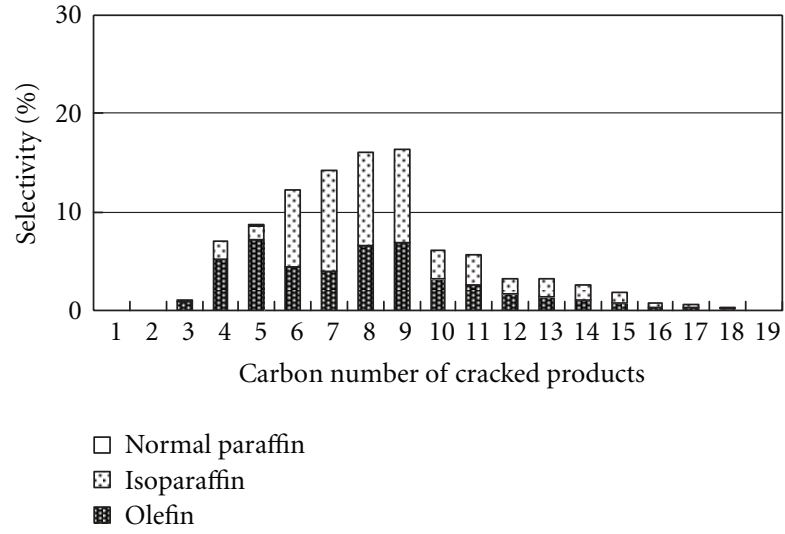

FIgure 8: Product distribution from catalytic cracking of hydrotreated oil over $\mathbf{n s ~} \mathrm{Al}_{2} \mathrm{O}_{3} / \mathrm{USY}$ catalyst at $350^{\circ} \mathrm{C}$.

TABLe 2: Basic physical properties of $\mathbf{n s} \mathrm{Al}_{2} \mathrm{O}_{3} / \mathrm{GaAlMFI}$ zeolite catalysts.

\begin{tabular}{lccc}
\hline Catalysts & $\begin{array}{c}\text { Surface area } \\
\left(\mathrm{m}^{2} / \mathrm{g}\right)\end{array}$ & $\begin{array}{c}\text { Pore volume } \\
(\mathrm{mL} / \mathrm{g})\end{array}$ & $\begin{array}{c}\text { Average pore } \\
\text { diameter }(\mathrm{nm})\end{array}$ \\
\hline $\mathrm{H}-\mathrm{GaAlMFI}$ & 333 & 0.29 & 3.5 \\
$\mathbf{n s ~} \mathrm{Al}_{2} \mathrm{O}_{3}$ & 313 & 0.44 & 5.7 \\
$\mathbf{n s ~} \mathrm{Al}_{2} \mathrm{O}_{3} / \mathrm{H}-\mathrm{GaAlMFI}$ & 216 & 0.41 & 7.6 \\
$\mathbf{n s}$ & 319 & 0.39 & 5.0 \\
$\mathrm{Al}_{2} \mathrm{O}_{3}+\mathrm{H}-\mathrm{GaAlMFI}^{*}$ & & & \\
${ }^{*}$ Theoretical addition by composition. & &
\end{tabular}

3.3.2. ns $\mathrm{Al}_{2} \mathrm{O}_{3} / \mathrm{H}$-GaAlMFI Zeolite Catalyst. ns $\mathrm{Al}_{2} \mathrm{O}_{3} / \mathrm{H}$ GaAlMFI zeolite catalyst was developed for cracking reforming of heavier $n$-paraffins [37]. The properties of the catalyst are shown in Table 2. The catalyst generated new acid sites at the boundary between $\mathbf{n s} \mathrm{Al}_{2} \mathrm{O}_{3}$ and GaAlMFI zeolite. In addition, as shown in Figure 9, the Ga species can be extracted to the surface layer by calcination, protonation, and composition. The extracted Ga species has a relatively high activity for aromatization.

Catalytic cracking of hydrotreated oil was investigated over ns $\mathrm{Al}_{2} \mathrm{O}_{3} / \mathrm{H}$-GaAlMFI zeolite catalyst with contact times in the range 0.025 to $0.1 \mathrm{~h}$ and at temperatures in the range 400 to $500^{\circ} \mathrm{C}$. The results are shown in Figures 10, 11, and 12.

As shown in Figure 10, at the longer contact time, the aromatics yield was increased and many polycyclic aromatics were produced in $0.1 \mathrm{~h}$. n-paraffins also increased due to hydrogen transfer reactions. Therefore, $0.05 \mathrm{~h}$ was selected as the optimum contact time.

As shown in Figure 11, comparing the conversions among reaction temperatures, the maximum value was about $80 \%$ at $500^{\circ} \mathrm{C}$. Typically, conversion increases with increasing reaction temperature. However, the conversion decreased at $550^{\circ} \mathrm{C}$. A large amount of polycyclic aromatics were observed in the product oil at high temperatures, especially at $550^{\circ} \mathrm{C}$. Therefore, it was considered that a large amount of coke was produced, which caused rapid 


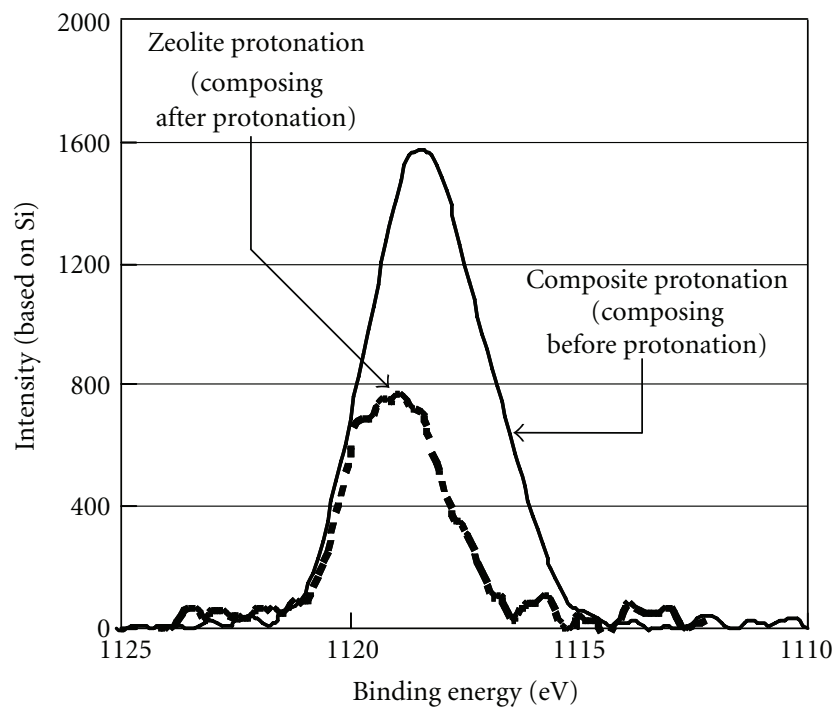

FIgURE 9: Ga 2p XPS spectra of $\mathbf{n s ~} \mathrm{Al}_{2} \mathrm{O}_{3} / \mathrm{GaAlMFI}$ zeolite catalyst.

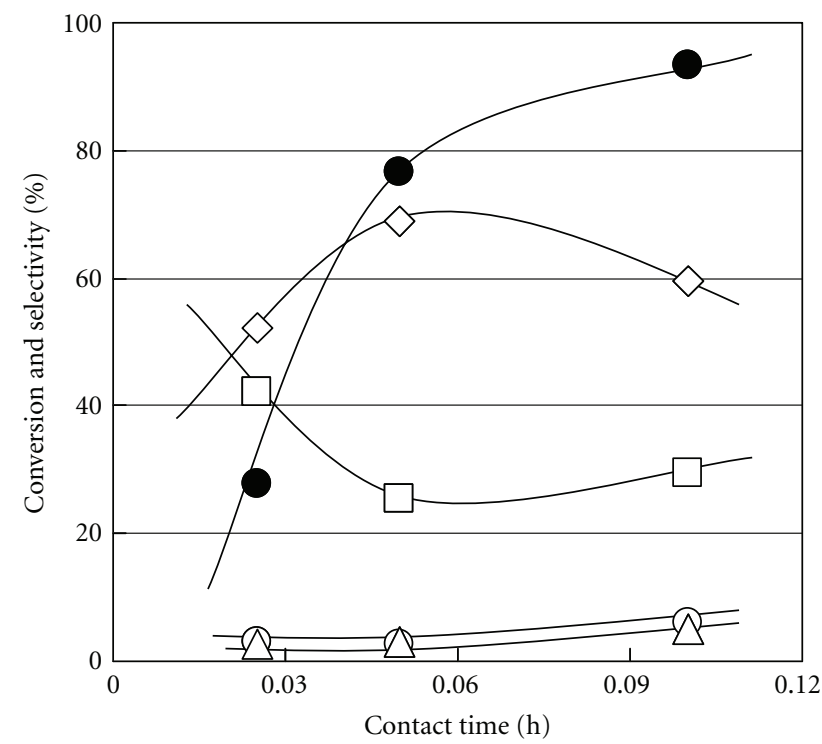

FIGURE 10: Conversion and product selectivity of catalytic cracking of hydrotreated oil over $\mathbf{n s ~} \mathrm{Al}_{2} \mathrm{O}_{3} / \mathrm{H}$-GaAlMFI catalyst depending on contact time. ๑: Conversion; selectivity: $\bigcirc$ : normal paraffins; $\triangle$ : isoparaffins; $\square$ : olefins; $\diamond$ : aromatics.

degradation of the catalyst. It was demonstrated that the optimum reaction temperature for the catalyst was $500^{\circ} \mathrm{C}$.

As shown in Figure 12, the main aromatic products were toluene, xylenes, and benzene. The reaction scheme of catalytic cracking of hydrotreated oil based on Figures 8 and 12 is summarized in Figure 13. As shown in Figure 13, aromatics were produced by oligomerization and aromatization of cracked olefins. $\mathbf{n s} \mathrm{Al}_{2} \mathrm{O}_{3} /$ USY zeolite catalyst does not cause aromatization, whereas MFI-type zeolite does and $\mathrm{Ga}$ promotes dehydrogenation. Therefore, ns $\mathrm{Al}_{2} \mathrm{O}_{3} / \mathrm{H}-$ GaAlMFI could have produced most of the aromatics in this study.

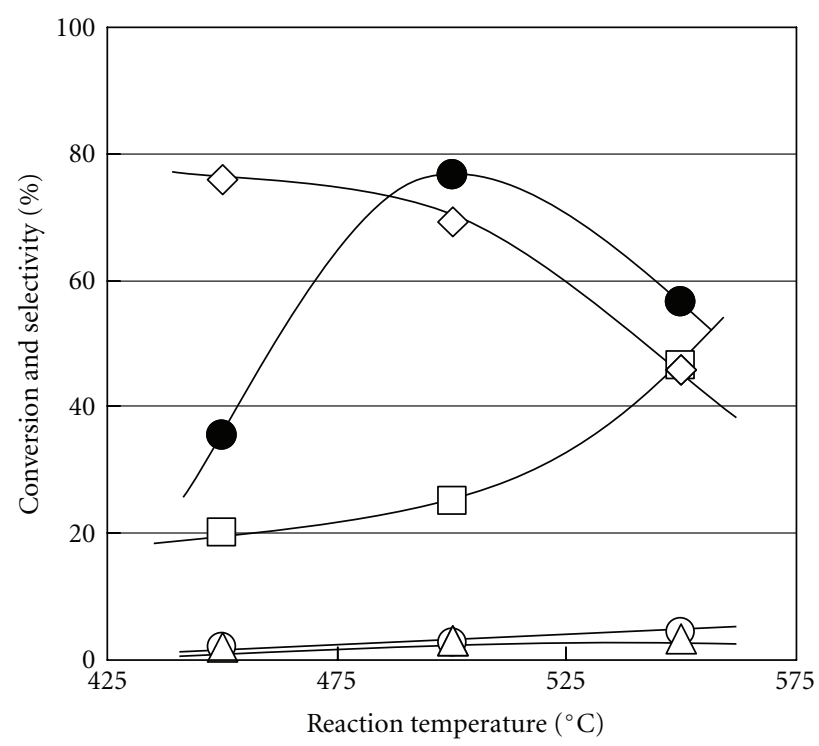

FIGURE 11: Conversion and product selectivity of catalytic cracking of hydrotreated oil over $\mathbf{n s} \mathrm{Al}_{2} \mathrm{O}_{3} / \mathrm{H}$-GaAlMFI catalyst depending on reaction temperature. 0 : Conversion; selectivity: $\bigcirc$ : normal paraffins; $\triangle$ : isoparaffins; $\square$ : olefins; $\diamond$ : aromatics.

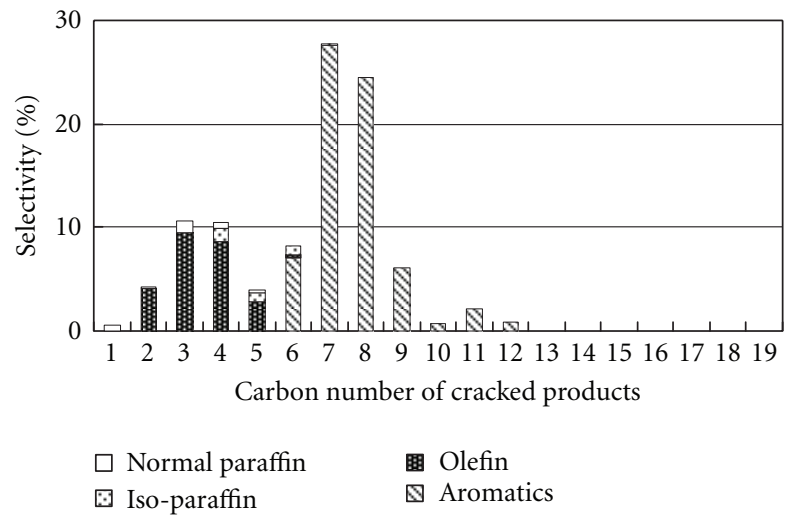

Figure 12: Product distribution of catalytic cracking of hydrotreated oil over ns $\mathrm{Al}_{2} \mathrm{O}_{3} / \mathrm{H}-\mathrm{GaAlMFI}$ catalyst at $500^{\circ} \mathrm{C}$ (contact time: $0.05 \mathrm{~h}$ ).

3.4. Hydrocracking of Hydrotreated Oil. Hydrocracking of hydrotreated oil was investigated over $\left[\mathrm{NiMo} / \gamma-\mathrm{Al}_{2} \mathrm{O}_{3}\right] / \mathbf{n s}$ $\mathrm{Al}_{2} \mathrm{O}_{3} / \mathrm{H}$-beta zeolite catalyst at temperatures in the range 250 to $350^{\circ} \mathrm{C}$. The results are shown in Figures 14 and 15 .

As shown in Figure 14, the catalytic performance was very high. The conversion was over $90 \%$ and isoparaffins selectivity was about $90 \%$ at $300^{\circ} \mathrm{C}$. As shown in Figure 15, the cracking reaction was suppressed and the product distribution of carbon number at $275^{\circ} \mathrm{C}$ had a peak at 10 . At higher temperatures, the cracking reaction progressed and the product distribution of carbon number at $350^{\circ} \mathrm{C}$ had a peak at 7 (data not shown). Thus, the product distribution could be controlled by changing the reaction temperature on $\left[\mathrm{NiMo} / \gamma-\mathrm{Al}_{2} \mathrm{O}_{3}\right] / \mathbf{n s ~} \mathrm{Al}_{2} \mathrm{O}_{3} / \mathrm{H}$-beta zeolite catalyst. It was demonstrated that the optimum reaction temperature was $275 \sim 300^{\circ} \mathrm{C}$. 


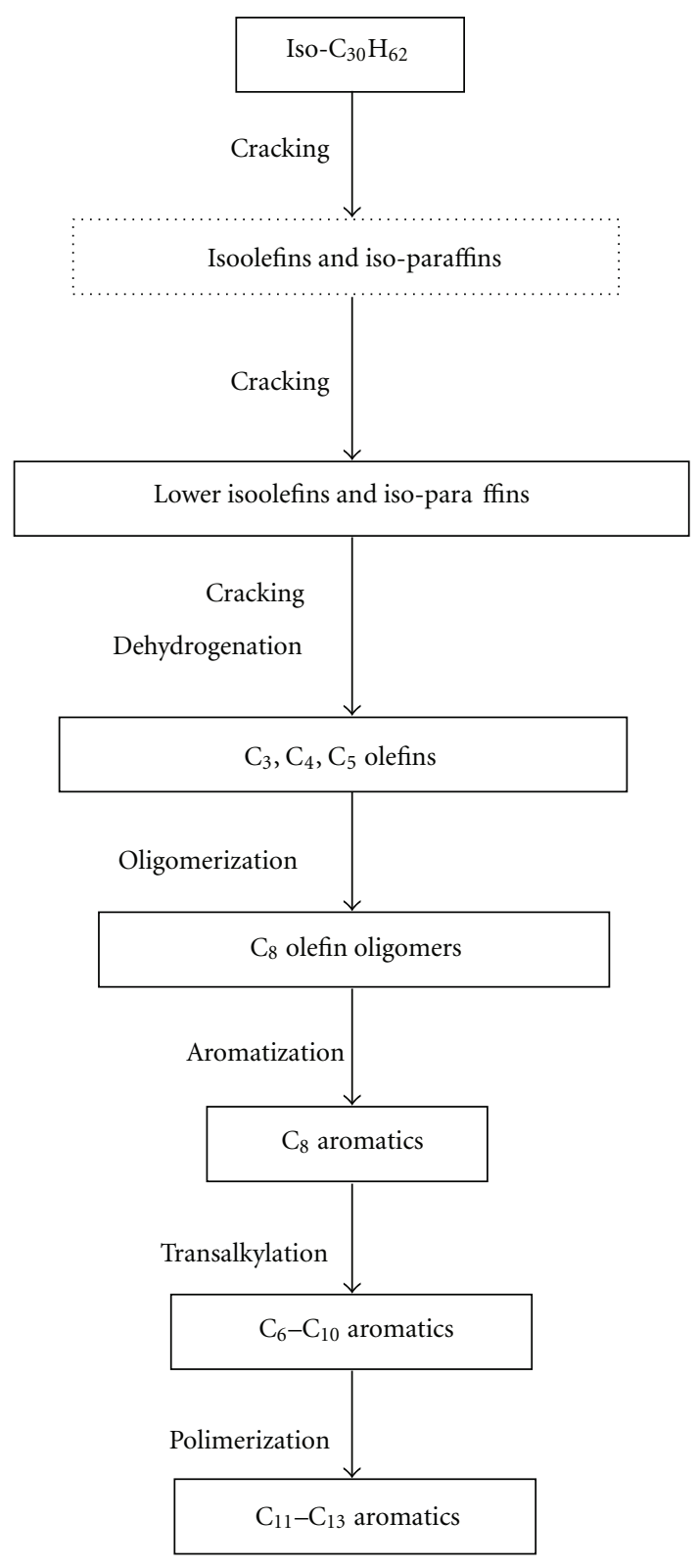

FIGURE 13: Reaction scheme of catalytic cracking of hydrotreated oil over $\mathbf{n s ~} \mathrm{Al}_{2} \mathrm{O}_{3} / \mathrm{USY}$ and $\mathbf{n s} \mathrm{Al}_{2} \mathrm{O}_{3} / \mathrm{H}$-GaAlMFI zeolite catalyst based on Figures 8 and 12.

3.5. Evaluation of Processes. These four processes (CC: catalytic cracking; HC: hydrocracking; HT-CC: hydrotreatingcatalytic cracking; HT-HC: hydrotreating hydrocracking) were compared in terms of conversion and product selectivities under optimum reaction conditions. The results are shown in Table 3. Comparison of the obtained fuel fraction and hydrogen consumption is shown in Table 4 and the evaluation summary of these processes is shown in Figure 16.

As shown in Table 3, the products of CC were olefinic because the material contains only a small amount of hydrogen. It was considered that hydrocracking used hydrogen in the carrier gas, but selectivity for olefins was still less than in CC. The products from HT-CC on $\mathbf{n s} \mathrm{Al}_{2} \mathrm{O}_{3} / \mathrm{USY}$

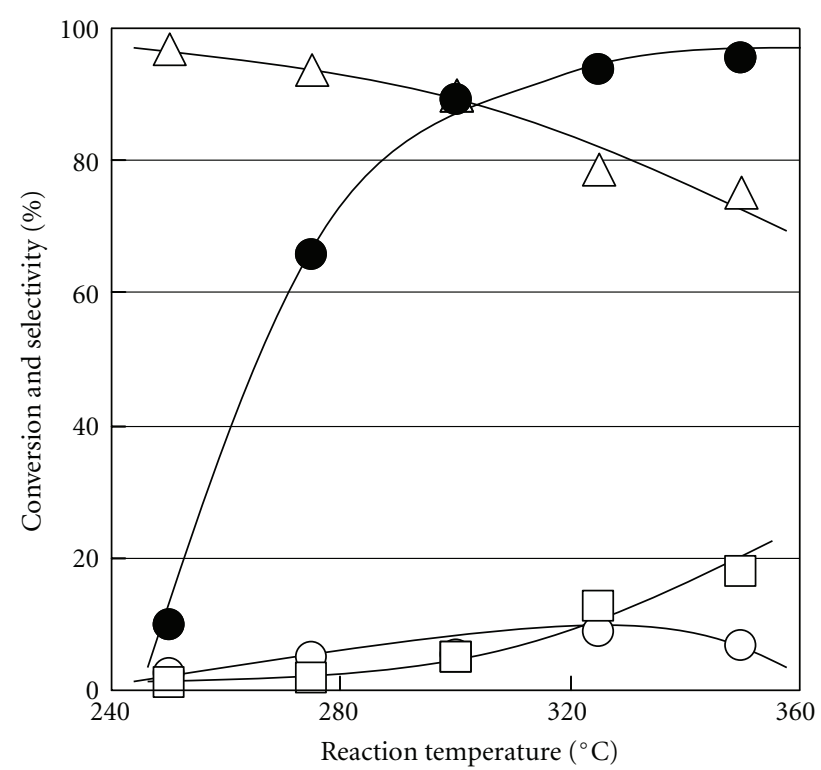

FIGURE 14: Conversion and product selectivity of hydrocracking of hydrotreated oil over $\left[\mathrm{NiMo} / \gamma-\mathrm{Al}_{2} \mathrm{O}_{3}\right] / \mathbf{n s ~} \mathrm{Al}_{2} \mathrm{O}_{3} / \mathrm{H}$-beta zeolite catalyst depending on reaction temperature. $\bullet$ : Conversion; selectivity: $\bigcirc$ : normal paraffins; $\Delta$ : isoparaffins; $\square$ : olefins.

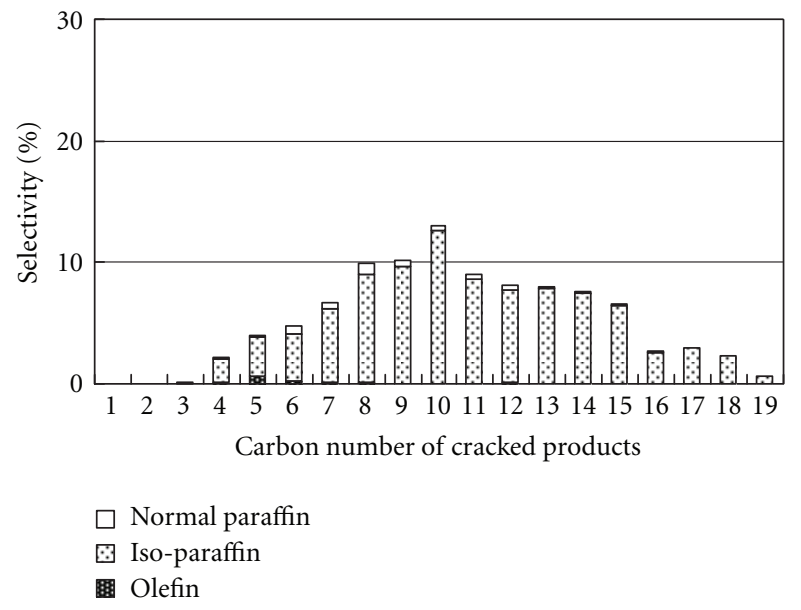

FIGURE 15: Product distribution of hydrocracking of hydrotreated oil over $\left[\mathrm{NiMo} / \gamma-\mathrm{Al}_{2} \mathrm{O}_{3}\right] /$ ns $\mathrm{Al}_{2} \mathrm{O}_{3} / \mathrm{H}$-beta Zzeolite catalyst at $275^{\circ} \mathrm{C}$.

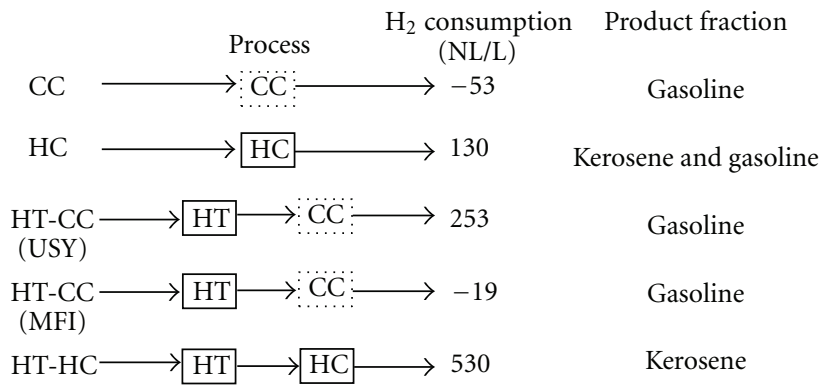

FIGURE 16: Evaluation of processes. 
TABLE 3: Comparison of catalytic performance in various processes.

\begin{tabular}{lccccc}
\hline Process & CC & HC & HT-CC (USY) & HT-CC (MFI) & HT-HC \\
\hline Conversion (\%) & 100.0 & 94.9 & 93.3 & 52.8 & 3.1 \\
isopara. sel. (\%) & 15.2 & 34.3 & 46.9 & 25.0 & 89.7 \\
olefins sel. (\%) & 57.6 & 25.6 & 0.0 & 69.2 & 0 \\
aroma. sel. (\%) & 26.0 & 39.6 & 8.2 & 6.3 \\
\hline Ave. Carbon number of cracked & 10.1 & 9.6 & 10.8 \\
\hline
\end{tabular}

TABLE 4: Comparison of the obtained fuel fraction from various processes.

\begin{tabular}{|c|c|c|c|c|c|}
\hline Process & $\mathrm{CC}$ & $\mathrm{HC}$ & HT-CC (USY) & HT-CC (MFI) & HT-HC \\
\hline Conversion (\%) & 100.0 & 94.9 & 93.3 & 76.6 & 89.2 \\
\hline LPG sel. (\%) & 5.3 & 2.2 & 8.1 & 21.1 & 2.3 \\
\hline Gasoline sel. (\%) & 35.4 & 32.8 & 51.2 & 64.5 & 25.4 \\
\hline Kerosene sel. (\%) & 54.1 & 60.0 & 39.1 & 9.7 & 62.4 \\
\hline Diesel sel. (\%) & 2.0 & 4.7 & 1.7 & 0.0 & 9.9 \\
\hline Hydrogen consumption (NL/L) & -53.1 & 130.1 & 253.9 & -19.1 & 530.0 \\
\hline
\end{tabular}

zeolite catalyst were isoparaffins and olefins. Aromatics were not produced due to low temperatures and the mild cracking ability of this catalyst. The products from HT$\mathrm{CC}$ on $\mathbf{n s} \mathrm{Al}_{2} \mathrm{O}_{3} / \mathrm{H}-\mathrm{GaAlMFI}$ zeolite catalyst were mostly aromatics because this catalyst has high aromatization and dehydrogenation abilities. On the other hand, the products of HT-HC were isoparaffins due to the relatively mild cracking ability of the catalyst.

As shown in Table 4 and Figure 16, the major fuel fractions from $\mathrm{CC}$ on $\mathbf{n s} \mathrm{Al}_{2} \mathrm{O}_{3} / \mathrm{H}$-USY were gasoline and kerosene, while those from $\mathrm{HC}$ were half-isoparaffinic/olefinic kerosene and gasoline. Although more than $50 \mathrm{wt} \%$ of the products from HT-CC on the USY catalyst were isoparaffinic/olefinic gasoline, the products from HT-CC on the MFI catalyst at ca. $500^{\circ} \mathrm{C}$ were high-octane-number gasoline including aromatics. Furthermore, an external hydrogen supply was not required in HT-CC on the MFI catalyst. Attractively, the carbon number distribution of the products from $\mathrm{HT} / \mathrm{HC}$ at $275 \sim 300^{\circ} \mathrm{C}$ populated the kerosene region and its average carbon number was between 10 and 11 , while more than $80 \mathrm{wt} \%$ was isoparaffinic. It was demonstrated that the fuel produced can be used as kerosene.

\section{Conclusion}

Various hybrid zeolite catalysts with $\mathbf{n s} \mathrm{Al}_{2} \mathrm{O}_{3}$ had high performance for HT-CC and HT-HC from isoprenoid oil derived from microalgae to afford gasoline, aromatics, and kerosene, while required hydrogen consumption increased in the order $\mathrm{CC}<\mathrm{HT}-\mathrm{CC}(\mathrm{MFI})<\mathrm{HC}<\mathrm{HT}-\mathrm{CC}(\mathrm{USY})<\mathrm{HT}-$ HC. Isoparaffinic/olefinic gasoline could be produced by hydrotreating-catalytic cracking on ns $\mathrm{Al}_{2} \mathrm{O}_{3} / \mathrm{H}$-USY catalyst; high-octane-number aromatics-rich gasoline could be produced without an external hydrogen supply by hydrotreating-catalytic cracking on ns $\mathrm{Al}_{2} \mathrm{O}_{3} / \mathrm{H}-\mathrm{GaAlMFI}$ catalyst. While hydrotreating hydrocracking on $[\mathrm{NiMo} / \gamma$ $\left.\mathrm{Al}_{2} \mathrm{O}_{3}\right] /$ ns $\mathrm{Al}_{2} \mathrm{O}_{3} / \mathrm{H}$-beta catalysts required a good supply of hydrogen, isoparaffins-rich kerosene could be produced at low temperatures.

\section{Acknowledgments}

The authors gratefully acknowledge the financial support from CREST-JST (Japan Science and Technology Agency) and the assistance of their coworkers, H. Sata and S. Sudo.

\section{References}

[1] E. Kitray, "The role of renewable energy sources in meeting Turkey's electrical energy demand," Energy Education Science and Technology A, vol. 23, p. 15, 2009.

[2] F. A. Zaher and A. R. Taman, "Thermally decomposed cottonseed oil as a diesel engine fuel," Energy Sources, vol. 15, no. 3, pp. 499-504, 1993.

[3] D. Pioch, P. Lozano, M. C. Rasoanantoandro, J. Graille, P. Geneste, and A. Guida, "Biofuels from catalytic cracking of tropical vegetable oils," Oléagineux, vol. 48, pp. 289-292, 1993.

[4] A. Srivastava and R. Prasad, "Triglycerides-based diesel fuels," Renewable \& Sustainable Energy Reviews, vol. 4, no. 2, pp. 111133, 2000.

[5] O. Y. Sang, F. Twaiq, R. Zakaria, A. R. Mohamed, and S. Bhatia, "Biofuel production from catalytic cracking of palm oil," Energy Sources, vol. 25, no. 9, pp. 859-869, 2003.

[6] Y. S. Ooi, R. Zakaria, A. R. Mohamed, and S. Bhatia, "Synthesis of composite material MCM-41/Beta and its catalytic performance in waste used palm oil cracking," Applied Catalysis A, vol. 274, no. 1-2, pp. 15-23, 2004.

[7] Y. S. Ooi, R. Zakaria, A. R. Mohamed, and S. Bhatia, "Catalytic conversion of palm oil-based fatty acid mixture to liquid fuel," Biomass and Bioenergy, vol. 27, no. 5, pp. 477-484, 2004.

[8] S. Bhatia, "Catalytic conversion of fatty acid mixture to liquid fuels over mesoporous material," Reaction Kinetics and Catalysis Letters, vol. 84, no. 2, pp. 295-302, 2005.

[9] A. A. Lappas and I. A. Vasalos, "Catalytic cracking to liquids (BTL) fuels with novel cracking catalyst," in 232nd American Chemical Society Meeting and Exposition, usa, September 2006. 
[10] M. Asadullah, T. Miyazawa, S. I. Ito, K. Kunimori, and K. Tomishige, "Demonstration of real biomass gasification drastically promoted by effective catalyst," Applied Catalysis A, vol. 246, no. 1, pp. 103-116, 2003.

[11] M. Inaba, K. Murata, M. Saito, and I. Takahara, "Hydrogen production by gasification of cellulose over $\mathrm{Ni}$ catalysts supported on zeolites," Energy and Fuels, vol. 20, no. 2, pp. 432438, 2006

[12] T. Kimura, T. Miyazawa, J. Nishikawa et al., "Development of Ni catalysts for tar removal by steam gasification of biomass," Applied Catalysis B, vol. 68, no. 3-4, pp. 160-170, 2006.

[13] Y. Chisti, "Biodiesel from microalgae," Biotechnology Advances, vol. 25, no. 3, pp. 294-306, 2007.

[14] A. L. Ahmad, N. H. M. Yasin, C. J. C. Derek, and J. K. Lim, "Microalgae as a sustainable energy source for biodiesel production: a review," Renewable and Sustainable Energy Reviews, vol. 15, no. 1, pp. 584-593, 2011.

[15] K. M. Lam and T. K. Lee, "Microalgae biofuels: a critical review of issues, problems and the way forward," Biotechnology Advances, vol. 30, no. 3, pp. 673-690, 2012.

[16] J. Singh and S. Gu, "Commercialization potential of microalgae for biofuels production," Renewable and Sustainable Energy Reviews, vol. 14, no. 9, pp. 2596-2610, 2010.

[17] R. Harun, M. Singh, G. M. Forde, and M. K. Danquah, "Bioprocess engineering of microalgae to produce a variety of consumer products," Renewable and Sustainable Energy Reviews, vol. 14, no. 3, pp. 1037-1047, 2010.

[18] S. Amin, "Review on biofuel oil and gas production processes from microalgae," Energy Conversion and Management, vol. 50, no. 7, pp. 1834-1840, 2009.

[19] Y. H. Chen, B. Y. Huang, T. H. Chiang, and T. C. Tang, "Fuel properties of microalgae (Chlorella protothecoides) oil biodiesel and its blends with petroleum diesel," Fuel, vol. 94, pp. 270-273, 2012.

[20] Y. F. Yang, C. P. Feng, Y. Inamori, and T. Maekawa, "Analysis of energy conversion characteristics in liquefaction of algae," Resources, Conservation and Recycling, vol. 43, no. 1, pp. 2133, 2004.

[21] G. Guan and K. Kusakabe, "Synthesis of biodiesel fuel using an electrolysis method," Chemical Engineering Journal, vol. 153, no. 1-3, pp. 159-163, 2009.

[22] K. I. Suehara, Y. Kawamoto, E. Fujii, J. Kohda, Y. Nakano, and T. Yano, "Biological treatment of wastewater discharged from biodiesel fuel production plant with alkali-catalyzed transesterification," Journal of Bioscience and Bioengineering, vol. 100, no. 4, pp. 437-442, 2005.

[23] H. Kitazato, S. Asaoka, and H. Iwamoto, "Catalytic cracking of hydrocarbons from microalgae," Journal of the Japan Petroleum Institute, vol. 32, pp. 28-34, 1989.

[24] Y. Dote, S. Sawayama, S. Inoue, T. Minowa, and S. Y. Yokoyama, "Recovery of liquid fuel from hydrocarbon-rich microalgae by thermochemical liquefaction," Fuel, vol. 73, no. 12, pp. 1855-1857, 1994.

[25] D. A. Chia and D. L. Trimm, "The effect of pre-coking on the activity and selectivity of the catalytic cracking of squalane," Journal of Chemical Technology and Biotechnology, vol. 80, no. 3, pp. 353-355, 2005.

[26] P. Metzger and C. Largeau, "Botryococcus braunii: a rich source for hydrocarbons and related ether lipids," Applied Microbiology and Biotechnology, vol. 66, no. 5, pp. 486-496, 2005.

[27] K. Tsukahara and S. Sawayama, "Liquid fuel production using microalgae," Journal of the Japan Petroleum Institute, vol. 48, no. 5, pp. 251-259, 2005.
[28] T. Kimura, K. Sakashita, and S. Asaoka, "Preparation of nanosized and structured oxides for catalyst ," Materials Research Innovations, vol. 15, supplement 2, pp. s101-s105, 2011.

[29] S. Asaoka, K. Ito, S. Minohara, M. Ashraf Ali, and H. S. Bamufleh, "Principle design and trial for hydrotreating/ hydrocracking catalyst," in 232nd American Chemical Society Meeting and Exposition, usa, September 2006.

[30] M. A. Ali and S. Asaoka, "Ni-Mo-titania-alumina catalysts with usy zeolite for low pressure hydrodesulfurization and hydrocracking," Petroleum Science and Technology, vol. 27, no. 10, pp. 984-997, 2009.

[31] K. Ito, H. Jang, K. Sakashita, and S. Asaoka, "Catalysis at the interface of nano-oxides and nanozeolites," Pure and Applied Chemistry, vol. 80, no. 11, pp. 2273-2282, 2008.

[32] K. Sakashita, M. Yoshino, I. Nishimura, and Y. Hayakawa, "Hydrocracking on consortium catalyst consisting of metals, nano-oxides and nano-zeolite," ACS Division of Petroleum Chemistry Preprints, vol. 54, no. 2, pp. 38-41, 2009.

[33] K. Sakashita, T. Kimura, M. Yoshino, and S. Asaoka, "NiMo/ $\mathrm{Al}_{2} \mathrm{O}_{3}$ promoted hybrid catalysts of nanosized alumina and beta zeolite for hydrocracking with isomerization," Journal of the Japan Petroleum Institute, vol. 54, no. 5, pp. 320-330, 2011.

[34] T. Kimura, K. Sakashita, X. Li, and S. Asaoka, "Conceptual design and preparation bases for nanoporous hydrocracking catalyst of metal, nano-oxide and zeolite," ACS Division of Petroleum Chemistry Preprints, vol. 56, no. 2, p. 65, 2011.

[35] T. Kimura, C. Liu, X. Li, and S. Asaoka, "Role of nanosized oxide in catalysis on the nanoporous surface of zeolite particles," Pure and Applied Chemistry. In press.

[36] T. Kimura, J. Gao, K. Sakashita, X. Li, and S. Asaoka, "Catalyst of palladium supported on $\mathrm{H}$-beta zeolite with nanosized $\mathrm{Al}_{2} \mathrm{O}_{3}$ for isomerization of $\mathrm{n}$-hexane," Journal of the Japan Petroleum Institute, vol. 55, no. 1, pp. 40-50, 2012.

[37] T. Kimura, K. Sakashita, X. Li, and S. Asaoka, "Catalyst of palladium supported on $\mathrm{H}$-Beta zeolite with nanosized $\mathrm{Al}_{2} \mathrm{O}_{3}$ for Isomerization of n-Heptane," Journal of the Japan Petroleum Institute, vol. 55, no. 2, pp. 99-107, 2012.

[38] T. Kimura, N. Hata, K. Sakashita, and S. Asaoka, "Production of aromatics from heavier $n$-paraffins on hybrid crackingreforming catalyst," Catalysis Today, vol. 185, no. 1, pp. 119$125,2012$.

[39] K. Sakashita, I. Nishimura, M. Yoshino, T. Kimura, and S. Asaoka, "Role of nanoporous $\mathrm{Al}_{2} \mathrm{O}_{3}$ as matrix for catalytic cracking," Journal of the Japan Petroleum Institute, vol. 54, no. 3, pp. 180-188, 2011.

[40] K. Sakashita, I. Nishimura, T. Kimura, and S. Asaoka, "Nanoporous $\mathrm{Al}_{2} \mathrm{O}_{3}$ designed as protecting matrix for zeolite in catalytic cacking," Journal of the Japan Petroleum Institute, vol. 54, no. 4, pp. 248-257, 2011. 

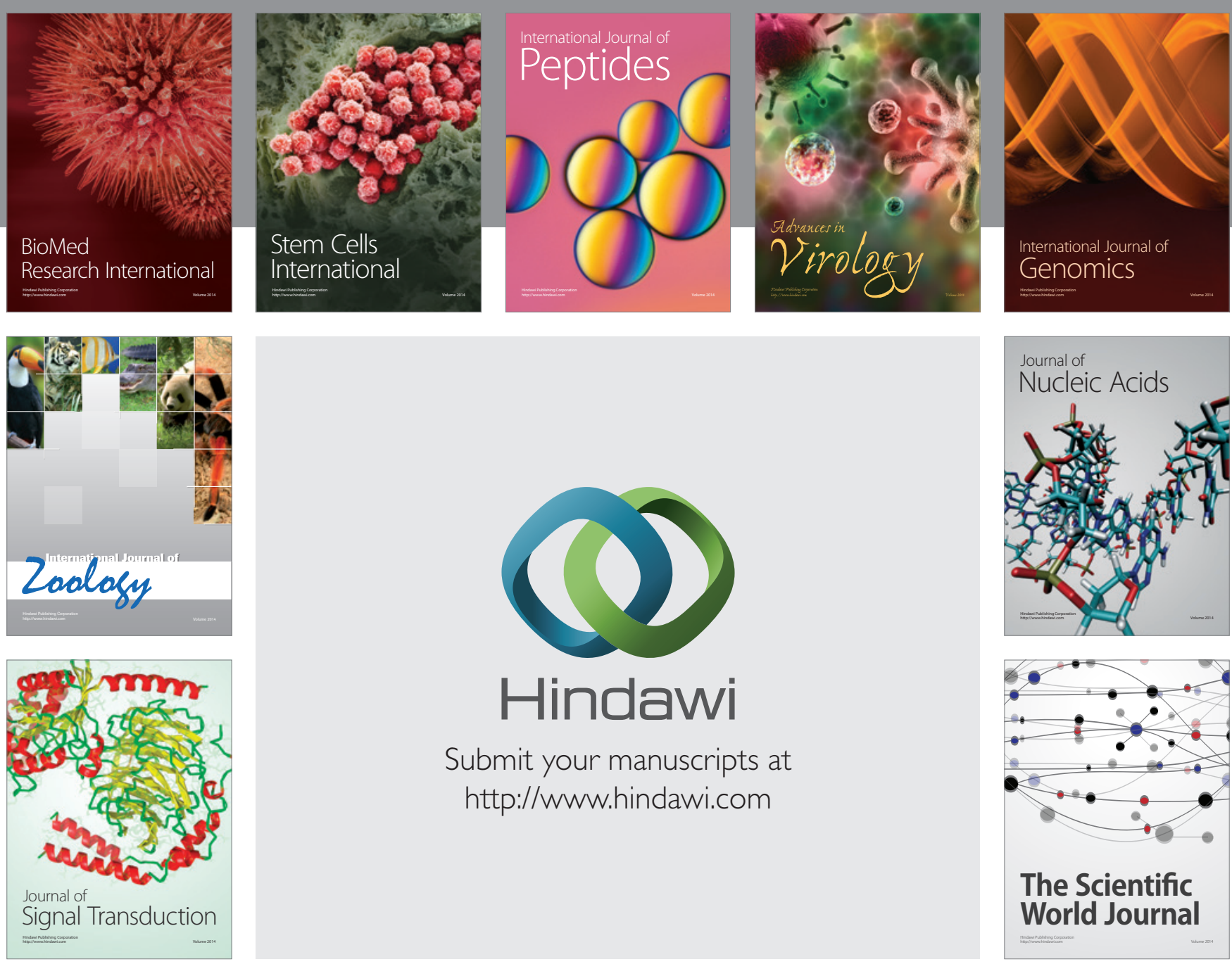

Submit your manuscripts at

http://www.hindawi.com
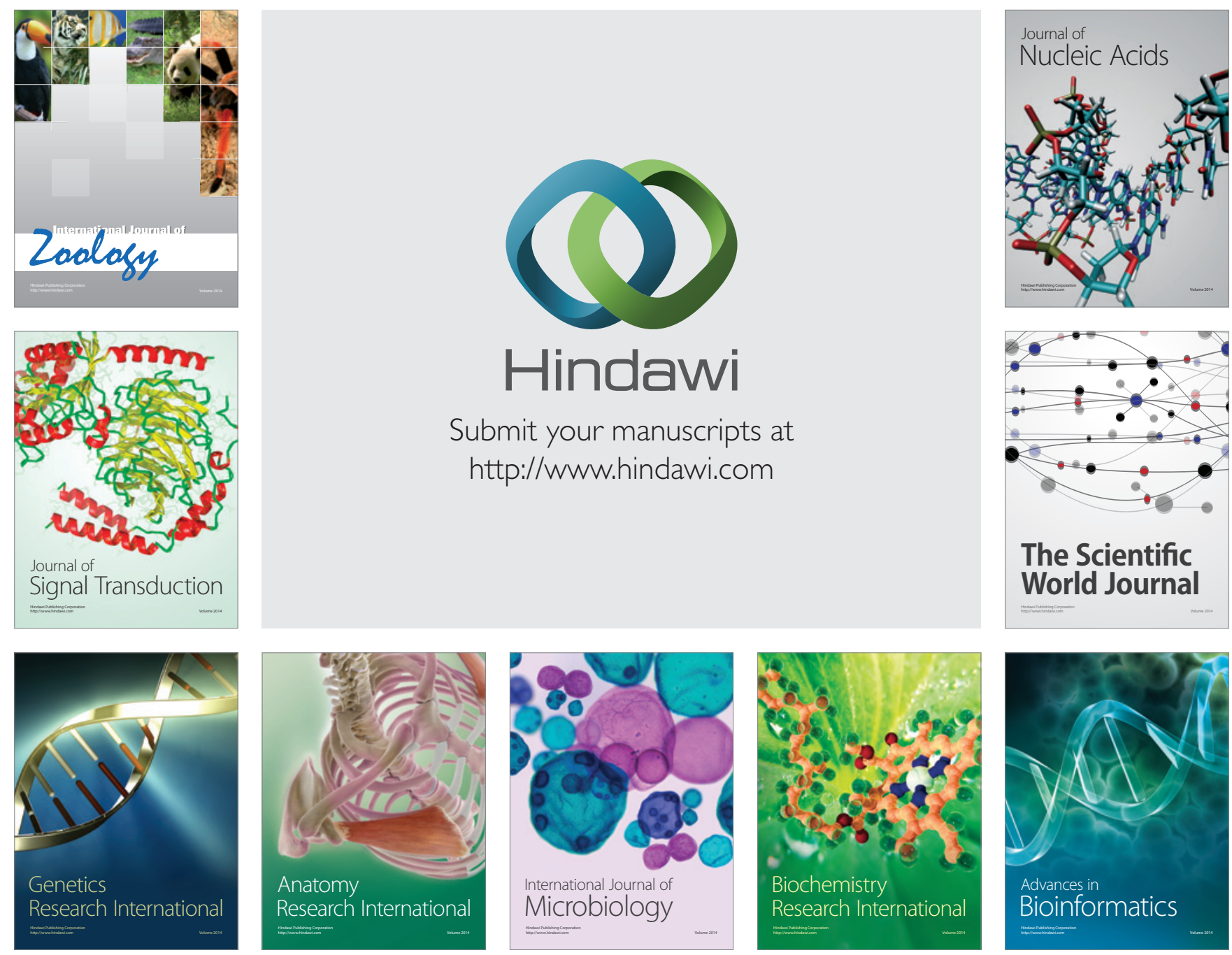

The Scientific World Journal
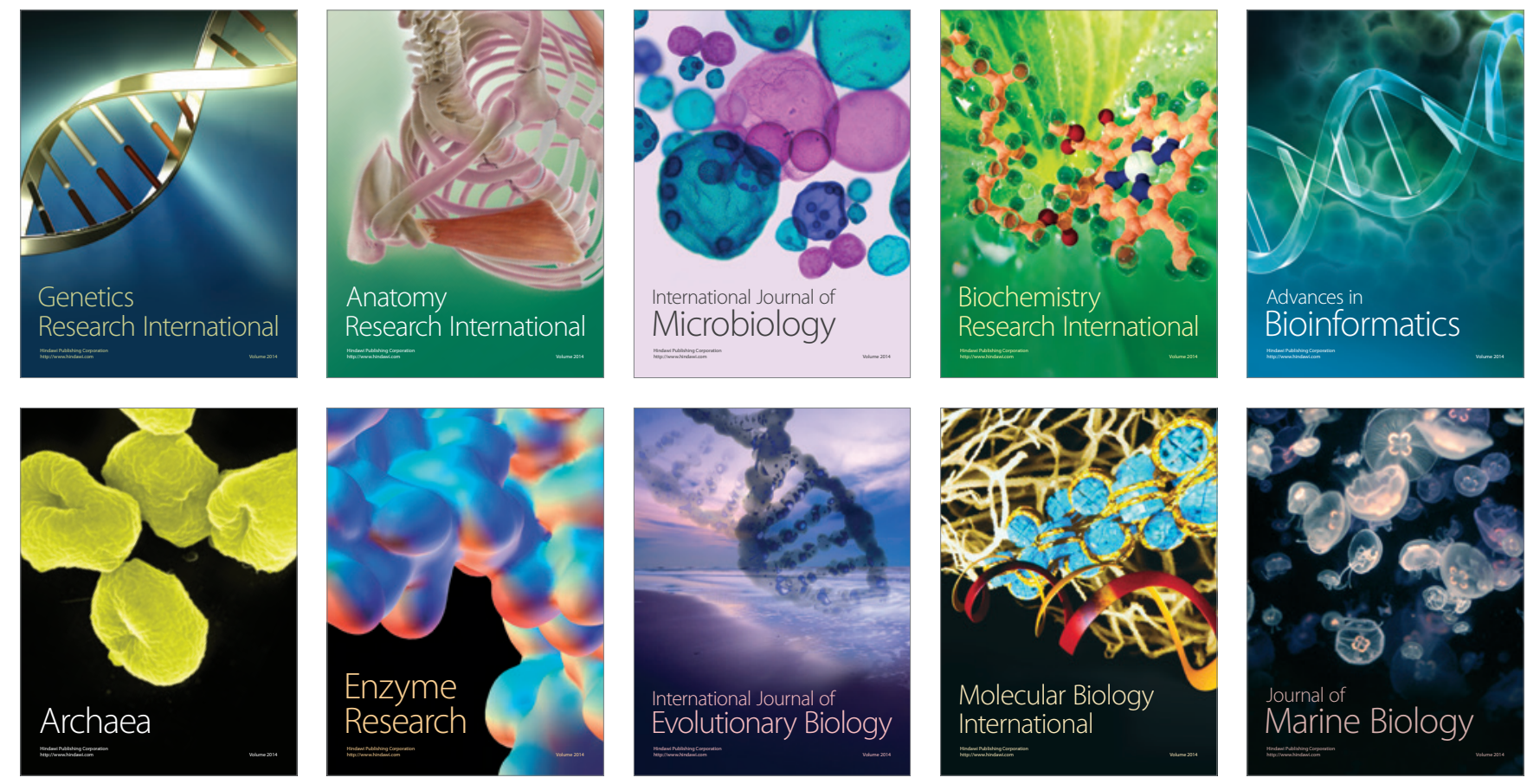